Creditors and the Feme Covert

James Oldham

Georgetown University Law Center, oldham@law.georgetown.edu

Georgetown Public Law and Legal Theory Research Paper No. 13-002

This paper can be downloaded free of charge from:

https://scholarship.law.georgetown.edu/facpub/1148

http://ssrn.com/abstract=2197268

Creditors and the Feme Covert, in LAW AND LEGAL PROCESS (M. Dyson and D. Ibbetson, eds., Cambridge University Press 2013)

This open-access article is brought to you by the Georgetown Law Library. Posted with permission of the author. Follow this and additional works at: https://scholarship.law.georgetown.edu/facpub

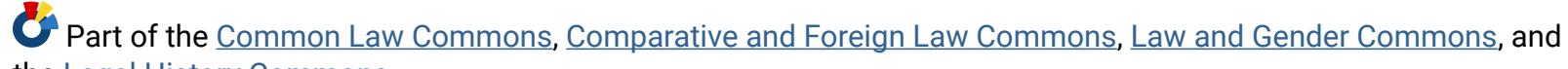
the Legal History Commons 


\title{
CREDITORS AND THE FEME COVERT
}

\author{
James Oldham* \\ [Forthcoming, in Law and Legal Process, D. Ibbetson and M. Dyson eds. \\ (Cambridge University Press, 2013)]
}

\section{Introduction}

William Blackstone in his Commentaries explained that, 'By marriage the husband and wife are one person in law: that is, the very being or legal existence of the woman is suspended during marriage, or is at least incorporated and consolidated into that of the husband, under whose wing, protection, and cover she performs everything. ${ }^{1}$ Despite this flat declaration, there was a steady stream of lawsuits against married women in the late eighteenth and early nineteenth centuries. Most of the cases were brought by tradesmen or merchants seeking payment for services rendered or goods sold. The typical contexts were two: when married women transacted business as if single, as femes sole, and when married women lived separate from their husbands and purchased goods or services for subsistence, as 'necessaries'.

Even when Blackstone wrote, exceptions to the 'unity of the persons' theory had been recognised. The established rules were summarised by De Grey CJCP in 1776 in the case of Hatchett v. Baddeley. ${ }^{2}$ The defendant had eloped from her husband and lived separate and apart from him; plaintiffs performed work for the defendant at her request and on her credit only. After stating the baseline rule with more specificity than did Blackstone, ${ }^{3}$ De Grey noted the existence of exceptions

\footnotetext{
${ }^{*}$ St. Thomas More Professor of Law and Legal History, Georgetown Law Center.

${ }^{1}$ W. Blackstone, Commentaries on the Laws of England (1765-69), vol. I, 430, citing Coke on Littleton 112.

22 W. BI. 1079 (1776). In Blackstone's report of the case, De Grey CJ's opinion occupies but a single printed page. A manuscript copy of the case, however, contains a fuller report: Buller and East, 'Manuscript Notes of Cases 1754-1792', Part II, Misc. MS 97, Inner Temple Library, London, 132. The quotations of De Grey's opinion in the text and footnotes that follow are taken from the manuscript report unless otherwise indicated.

3 'It is a clear general rule that the effect of a woman's marriage is to divest her of her personal property, of all power of contracting, and so of administering, or disposing of the effects of the husband without his consent, though she lives with him. The necessary consequence of this is, she cannot sue or be sued, for were she able to sue or liable to be sued, this would imply civil contracts and engagements.'
} 
for local customs, such as 'the wife's trading as feme sole in the City of London'. Also, the husband's actions or circumstances could make the wife effectively a feme sole, as when the husband was exiled from or had abjured the realm; likewise when the husband was or became an alien enemy. ${ }^{5}$

De Grey then asked how the law stood if the couple became separated because of the acts of the wife. His first response was:

If she voluntarily departs from him without his consent (not adulterously) it may be a breach of her moral duty, but the argument from thence that she contracts a new character, carries no conviction with it in my mind. This is no new ground of acquiring new rights. The coverture still remains. The husband's rights over her person and property remain as before. Her incapacities and obligations continue.

On the facts in Hatchett, the wife left her husband, though not adulterously, and the plaintiff knew this was so; thus: 'He, trusting her in that at least immoral state, must stand to it, as if he had trusted a feme sole trader in London in a matter not in the way of her trade.' The plaintiff's claim, therefore, failed.

Even clearer was the case of a wife who eloped with a lover - De Grey asked whether she had 'a power of revoking the consent of the husband and making herself a feme sole by a criminal act of adultery'? The answer was plainly 'no', since, 'If she be an adulterous one, it is true that by the canon and common law she cannot have alimony in the husband's life, nor by Westminster $2^{\mathrm{d}}$ dower after his death'. ${ }^{6}$ De Grey then asked, 'What then is to become of the wife? It is said she must starve. How so'? He was not moved by his rhetorical questions; rather, he thought:

This difficulty of procuring credit will oblige women to their duty. The making the separation

\footnotetext{
${ }^{4}$ On this custom, see, e.g., Jewson v. Read (1773) Lofft 134. There was a long tradition of married women trading as femes sole in medieval market towns. See sources cited at K. Pearlston, 'Judging the Judges: Mansfield and Kenyon on Coverture,' unpublished article, University of New Brunswick (2007), n. 5, available at:

http://amesfoundation.law.harvard.edu/BLHC07/Pearlston\%20Judging\%20the\%20Judges\%20vers\%203.3.pdf. Last accessed 3.11.2012

${ }^{5}$ See Derry v. Duke of Mazarine (1697) 1 Ld Raym 147, also reported as Dearly v. Duchess of Nazarine, 1 Salk 116 , and commonly referred to as the Duchess of Mazarine Case. Blackstone recognised 'one case where the wife shall sue and be sued as a feme sole, viz: where the husband has abjured the realm, or is banished': Blackstone, Commentaries, vol. 1, 431.

6 'Westminster $2^{d^{\prime}}$ refers to the Statue of Westminster II, 13 Edw. 1 (1285).
} 
easy would only induce them to desert their husbands. There is therefore no force in the argument of the wife's difficulty of procuring credit. Indeed, if her departure be adulterous, probably there is someone [who] will provide for her.

De Grey CJ did acknowledge that a married woman 'who quit [her husband] for his cruelty' could retain rights to alimony and dower, perhaps implying that in such circumstances she might be independently credit-worthy.

William Blackstone had been appointed to the Court of Common Pleas in 1770, where he served until his death a decade later. His views of the rights of married women remained fixed, and in the Hatchett case, he was 'clearly of opinion, that in no case can any feme covert be sued alone, except in the known excepted cases of abjuration, exile, and the like; where the husband is considered as dead, and the woman as a widow or else as divorced $a$ vinculo ${ }^{7}$ Blackstone added, for good measure, 'The rules of law should not be broken through for the sake of tradesmen. ${ }^{98}$

One situation recognised by the common law judges in the eighteenth century as analogous to a civil death was when the husband had been convicted of a felony and transported to the colonies for life. This was said to justify suit in England against the wife for her unpaid debts. ${ }^{9}$ In a trial on assize at Carlisle in 1768, Pearson v. Carruthers, Yates JKB extended the exception to a case of transportation for a term of years. The decision was not reported, but it became well known, because Yates privately canvassed the opinions of all the judges before giving his final decision. According to a manuscript report of Carruthers, the plaintiff brought an action of assumpsit against the defendant, who pleaded coverture, claiming 'that her husband had been alive and in Cumberland within three months of the trial' ${ }^{10}$ The plaintiff's response was that the husband had been 'convicted of a crime for which he had been transported, for a term of years not yet expired'. This was objected to by counsel

\footnotetext{
${ }^{7} 2$ W. Bl. at 1082, citing Coke on Littleton 133.

${ }^{8}$ Buller and East, Misc. MS 97, 141.

${ }^{9}$ Lord Mansfield in the Ringsted case remarked that he had decided such a case at the Maidstone assizes: 3 Doug at 198.

${ }^{10}$ Harvard Law School, MS 4057, f. 206, (1759-68). All references in the printed reports to the case before Yates J at the 1768 Carlisle assizes cite the case by the name of Sparrow v. Carruthers. From the descriptions, it is clear that it is the same case as that in the manuscript report under the name of Pearson v. Carruthers, or a parallel case brought by a different creditor.
} 
for the defendant, who argued 'that the wife was not suable as a feme sole, notwithstanding her husband's transportation, he being yet alive'. Yates J's opinion was that 'the circumstances of the case dissolved the wife's incapacity to contract,' but as a caution, he instructed that the verdict for the plaintiff was to be subject to the opinion of the Court of King's Bench. Afterwards, Yates reported that, 'the action being for a small sum, and the parties poor, he had not put them to the expence of arguing the point in court, but would take the opinion of the judges of B.R. upon it, out of court'. Later, he 'declared that all the judges of England were of opinion that the action well lay'. ${ }^{11}$

\section{The Court of King's Bench, Mansfield CJ}

A foretaste of Lord Mansfield's views on married women debtors came in a 1777 nisi prius case, Crompton v. Mackerill. ${ }^{12}$ There, the plaintiff sued a married woman for goods sold and delivered and work and labour performed in finishing and fitting up a house on St James Street. Lord Mansfield 'said that if a married woman was to pass as a single woman, he should have no doubt about the cause, for then she would not be permitted to say afterwards she was married, for that she would be a cheat'. In the case before him, however, it was proved that the plaintiff continued work after learning that the defendant was married, and thus he was not permitted to recover.

In the mid-1780s, a trilogy of cases brought on the full development of Lord Mansfield's views on married women debtors. In Ringsted v. Lady Lanesborough ${ }^{13}$ he repeated the fundamental rule that at common law, 'a wife has no civil capacity or power of acting without her husband, under

\footnotetext{
${ }^{11}$ Emphasis added. Apparently instead of approaching only King's Bench judges, Yates J put the case informally to the twelve judges at one of their periodic gatherings to consider questions reserved in crown cases and some civil cases. On this procedure, see J. Oldham, 'Informal Lawmaking in England by the Twelve Judges in the Late Eighteenth and Early Nineteenth Centuries' (2011) 29 Law and History Review 181. Yates's poll of the judges accounts for the recurrent references to the Carruthers case in other decisions even though the case was never reported. See the reference by Lord Mansfield CJ in Ringsted v. Lanesborough (1783) 3 Doug 197, 198; by Blackstone J in Lean v. Schutz (1783) 1 W BI 1195, 1197; by barrister John Scott (later Lord Eldon) in Corbett v. Poelnitz (1785) 1 TR 5, 6; by Buller J in De Gallion v. L'Aigle (1798) 1 B \& P 357; and by barrister Edward Law (later Lord Loughborough) in Marshall v. Rutton, text at n. 62, below.

12 Buller and East, 'Manuscript Notes of Cases 1754-1792', Part I, Misc. MS 96, Inner Temple Library, London, 70, sittings after Michaelmas 1777, Westminster Hall.

13 (1783) 3 Doug 197.
} 
whose absolute controul she is supposed to be'. ${ }^{14}$ But he also noted the established exceptions-when the husband had abjured the realm, was exiled, was a foreigner living abroad as an alien enemy, or was transported out of the kingdom, even if only for a term of years. On the facts of Ringsted, it was but a small step to allow the plaintiff to recover. The defendant and her late husband (who died before the action was brought) lived apart, he in Ireland and she in England. She had subsisted 'on ample separate maintenance', and since her husband, when alive, was 'not amenable to the process of the [English] courts', Mansfield and his fellow King's Bench judges thought that the case could be reasonably aligned with cases of abjuration and exile. He cautioned that 'the opinion we give will turn on all the circumstances of the case taken together and what I say will only apply to a case situated exactly like the present' ${ }^{15}$ Yet he also supported his holding in the case with the following comments: General rules are adapted to the frequent and ordinary state of the subject matter to which they relate, at the time when they are made. But in process of time, through the succession of ages, new manners arise, new modes of acting diversify the subject and beget cases within the letter but not within the reason of the general rule. Inconvenience, injustice and many absurdities must follow if the letter of a general rule was to govern cases not within the reason, \& therefore exceptions are implied from time to time, as the cases fit to be excepted arise, $\&$ the exceptions form a system of law together with the rule. ${ }^{16}$ A year later in Barwell v. Brooks ${ }^{17}$, Lord Mansfield extended the Ringsted exception to an action against a feme covert for necessaries even though both parties resided in England. The husband and wife lived separately, and the wife received a competent separate maintenance that was regularly paid. Again, Mansfield said that, 'modern fashions have altered the old law', and 'the courts have gone gradually for public convenience to enable women in these circumstances to carry on trade for

\footnotetext{
${ }^{14}$ The quotation is taken from Mansfield's handwritten opinion in the case, Scone Palace MSS First Series, Box 68. The autograph opinion contains a number of expressions omitted in Douglas's report. It should also be noted that Douglas's report of the case was not printed until volumes three and four of Douglas's Reports were published by editor Henry Roscoe in 1831.

${ }^{15} 3$ Doug at 206.

${ }^{16}$ Scone Palace MSS, First Series, Box 68.

${ }^{17}$ (1784) 3 Doug 371.
} 
their support and to prevent their becoming common cheats'. ${ }^{18}$ The plaintiff also argued that the husband should be joined as a defendant, but Mansfield had 'no difficulty in getting over that, notwithstanding the authority'. ${ }^{19}$ He said that, 'nothing can be so extravagant as to say in this case the husband must be joined, merely that the plaintiff may be nonsuited, for it is admitted that he [the husband] is not liable'. ${ }^{20}$

Finally, in Corbett v. Poelnitz, ${ }^{21}$ Mansfield took the largest step of all, allowing a creditor to sue a married woman living separately from her husband by agreement and having a large separate maintenance, even though both parties lived in England and the action was not limited to necessaries. He said that the three cases - Ringsted, Barwell, and Corbett - were fundamentally governed by 'the great principle which the Court has laid down, "that where a woman has a separate estate, and acts and receives credit as a feme sole, she shall be liable as such", ${ }^{22}$

The cases coming before the courts in the years that followed were varied, including more suits by creditors against married women who had behaved in the market place as if femes sole, and cases against husbands for necessaries extended to their wives. ${ }^{23}$ During 1787-8, Lord Mansfield was inactive due to failing health (though he survived until 1793), and Buller J was de facto chief justice. Buller continued to follow the line of cases that had culminated in Corbett v. Poelnitz. In Tunks v. Williams, the defendant and her husband lived separately and she had a separate maintenance; thus, as Buller told the jury, 'she alone is liable to pay all the debts she may contract; so far solemn decisions declare ${ }^{24}$ The jury returned a verdict for the plaintiff against Mrs Williams for $£ 27$, despite strong

\footnotetext{
${ }^{18}$ The quoted language is from a manuscript report of the Barwell case, Dampier Manuscripts, 'Cases in the King's Bench,' vol. 4, MS 49, Middle Temple Library, London, 68.

${ }^{19} 3$ Doug at 373.

${ }^{20}$ Dampier MSS 4, 68.

${ }^{21}(1785) 1$ TR 5.

${ }^{22} 1$ TR at 9.

${ }^{23}$ For a categorisation of the cases, see the extensive footnote by editor Henry Roscoe following his report of Ringsted in 3 Doug 204.

${ }^{24}$ The Times, September 29 1787, 3.
} 
evidence that the couple had been reconciled. ${ }^{25}$

\section{Kenyon CJ and Coverture Resurgent}

As is well-known, the 'great principle' stated by Lord Mansfield in Corbett v. Poelnitz did not sit well with his successor, Lloyd Kenyon. In several cases during the 1790s, Kenyon showed dissatisfaction with the expansion of married women's liability that Lord Mansfield had accomplished. ${ }^{26}$ In Gilchrist v. Brown, ${ }^{27}$ the King's Bench rejected a suit by a creditor against a married woman 'on promises on her own separate credit and account, in manner of a feme sole'. The defendant was separated from her husband, but the action could not be supported because it 'was destitute of the principle upon which all the late decisions have proceeded; in which it has been held that a feme covert may be sued as a feme sole, namely, a separate maintenance'. ${ }^{28}$

A separate question was what proof would be sufficient to establish the existence and continuation of a separate maintenance. In Stedman v. Gooch, ${ }^{29}$ Erskine, counsel for the plaintiff, offered proof of the Ecclesiastical Court's sentence of separation, and the receipt by the defendant

\footnotetext{
${ }^{25}$ According to another report of the case in The Times, June 201787,3 , the husband 'frequently visited the defendant, conversed with her in terms of familiarity, called her his dear and his dame, frequently dined and supped in her company, ... and went to her bed-chamber at ten and eleven at night; but whether he lay there or not was not proved, and it was admitted that she never went to his house'.

${ }^{26}$ Ironically, one of the earliest coverture cases to come before Lord Kenyon featured Lady Lanesborough, who had been before Lord Mansfield in the Ringsted case. Ganer v. Lady Lanesborough (1790) Peake 25, also in manuscript notes in a book kept by Vicary Gibbs, 'Cases at Nisi Prius 1782-1811', MS 17, Middle Temple Library, London, f.77. Ganer brought an action of debt on a judgment, and Lady Lanesborough's defence was that she was married to John King. According to the Gibbs manuscript, Ganer replied that King, a Jew, "had been before married to one Sara Lara, a Jewish woman', and this was supported by testimony of the clerk of the notary. The clerk had been at the wedding, and he said that it had been conducted 'according to the Jewish rites'. Peake's report states that Lady Lanesborough and King 'were divorced at Leghorn [Livorno, Italy] according to the rites and customs of the Jews there', and 'she produced an instrument under the seal of the synagogue there'. Lord Kenyon 'held this to be no evidence, for before he could take notice of any proceeding in a foreign Court, he must know the law of the country, which was a matter of evidence, and should be proved by witnesses', Peake at 25-26. Ultimately, Sara Lara was allowed to confirm the divorce by her own testimony, over the objection of the plaintiff that Lara was not a competent witness. The jury verdict was for the defendant.
}

${ }^{27}$ (1792) 4 TR 766.

${ }^{28} 4$ TR at 766-67.

${ }^{29}$ (1793) 1 Esp 3. 
from her husband of a regular annuity of $£ 200$ per annum payable at a London bank. At trial, according to Espinasse, Lord Kenyon seemed to think this proof sufficient, but the question was reserved for the full court. Espinasse ended his report by saying that when the case came on, 'the other Judges seemed to concur in opinion with Lord Kenyon; but no judgment has been given' ${ }^{30}$ In a subsequent report of the case in The Times, however, Kenyon mused that, 'The loose manners of the present time had rendered cases of this kind more frequent', and, 'When it was said, that laws were to be framed according to the custom of the times, he was afraid that was a most dangerous proposition; who was to set the fashion - where were they to find it? ${ }^{31}$ On the case before the court, he thought the annuity was ad arbitrium viri, something the husband could revoke at any moment, and without the security of a deed, the action would not lie. Grose and Ashhurst JJ agreed. Buller J disagreed, stating that 'in conscience and justice' the verdict should stand, and pointing out that when the $£ 200$ 'was deposited in the hands of a Banker, who in this case was in the nature of a trustee for the next year's maintenance, should the defendant not be liable to pay the debts she contracts during that year? ${ }^{32}$ In 1794 in Ellah v. Leigh $^{33}$ the plaintiff creditor answered the defendant's plea of coverture by explaining "that the defendant was separated from her husband, that alimony was allowed her by the Ecclesiastical Court pending a suit there, which was a sufficient maintenance, and that she obtained credit and made the promises on her own account as a feme sole and not on the credit of her husband'. Counsel for the plaintiff argued that the case came within the reason of Corbett v. Poelnitz, but to no avail. Clearly in direct response to the view expressed by Lord Mansfield in the Ringsted and Corbett cases, Lord Kenyon declared: 'I do not think that the courts ought to change the law so as to adapt it to the fashion of the times: if an alteration in the law be necessary, recourse must be had to the Legislature for it' ${ }^{34}$ Kenyon acknowledged that Corbett 'was indeed decided by great authority; and when a similar question arises, perhaps it may influence my judgment: but until such a case does

\footnotetext{
${ }^{30} \mathrm{lbid}$. at 8.

${ }^{31}$ The Times, 15 June 1793, 3.

${ }^{32}$ Ibid.

${ }^{33}$ (1794) 5 TR 679.

${ }^{34} 5$ TR at 682.
} 
arise, I shall suspend my opinion upon it ${ }^{35}$ But in the case at bar, analogous to the Stedman case, the wife's right to alimony during the pendency of the suit in the Ecclesiastical Court was not enough to constitute a separate maintenance; thus, the defendant's plea of coverture was upheld.

Two years later in Clayton v. Adams,${ }^{36}$ the Court of King's Bench again faced the coverture issue, this time in a suit by a creditor against the married woman's executor. Clayton claimed that the deceased 'carried on the trade and business of a haberdasher as a feme sole', and that he knew nothing of any husband. Counsel for the plaintiff conceded that, according to Ellah and other cases, the plaintiff could not have recovered against the testatrix herself, but argued that the defendant was liable as her executor, citing cases from the Court of Chancery. Without bothering to hear from the defendant's counsel, Lord Kenyon said that he fully subscribed to the equity cases, but a court of equity 'can give relief where a court of law cannot'. He stated that, 'A court of law cannot get at the property of the wife, if she have any', and 'if any one proposition in the law can be more clear than another it is this, that an action cannot be brought against a feme covert except by the custom of London'. Again alluding to Mansfield's views, he added: 'We must not, by any whimsical conceits supposed to be adapted to the altering fashions of the times, overturn the established law of the land: it descended to us as a sacred charge, and it is our duty to preserve it'. ${ }^{37}$

Lord Kenyon was less sure of himself when the husband was out of the country. In 1797 in two suits brought against the Duchess of Pienne, he was willing to allow creditors to sue the defendant when her husband (a foreigner) had gone abroad and had stayed away for several years. ${ }^{38}$ In the first of these, Walford v. Duchess of Pienne, Kenyon was pragmatic, saying that since the husband had deserted the kingdom, was no longer domiciled in England, and had been gone for years, the wife 'might be starved' if she could not be held liable for her debts because otherwise she would not be

\footnotetext{
${ }^{35}$ Ibid.

${ }^{36}$ (1796) 6 TR 604.

${ }^{37} 6$ T.R. at 605 . Lawrence $J$ in his manuscript notes of the case quotes Lord Kenyon as declaring, succinctly: 'The law protects us, and we ought to protect it'. Dampier Manuscripts, 'Lawrence Paper Book (“LPB") 107', Lincoln's Inn Library, London.

${ }^{38}$ See Walford v. Duchess of Pienne (1797) 2 Esp 554; Franks v. Duchess of Pienne (1797) 2 Esp 587.
} 
credit-worthy. ${ }^{39}$ According to The Times, Kenyon also said that there was no hope of the Duke's return, even though Espinasse reported that the plaintiff's witness believed the Duke had not abandoned his intention to return. ${ }^{40}$

Despite the outcome in the Duchess of Pienne cases, Lord Kenyon commented 'that some modern cases had, in his opinion, gone too far' ${ }^{41}$ Clearly he was hoping for an opportunity that would allow the judges to reassess the tangled mass of decisions involving creditors who did business with femes covert. Such an opportunity arrived in Marshall v. Rutton. The case was argued twice before eleven of the twelve judges - first on 9 May 1798 before all the justices except Perryn B, and again on 10 May 1800 before all the justices except Buller J. The action was brought in assumpsit on the common counts for goods sold, money laid out, and work performed for the defendant, who pleaded her coverture. The plaintiff replied that the defendant and her husband had mutually covenanted and agreed to live separate and apart, and that a competent separate maintenance of $£ 200$ per annum had been secured to the defendant by deed and had been duly paid to her.

The report of the Marshall case published by Durnford and East in the Term Reports is relatively brief, containing only Lord Kenyon's judgment. According to that report, Kenyon described the general question as 'whether by any agreement between a man and his wife, she may be made legally responsible for the contracts she may enter into, and be liable to the actions of those who may have trusted to her engagements, as if she were sole and unmarried' ${ }^{42}$ He then stated that, after two arguments before all the judges, 'and after a very full consideration, the opinion of all the judges who heard the last argument is, that this action cannot be supported'. He tipped his hand early in his opinion by stating that the agreement between husband and wife to live separate and apart from each other was 'a contract supposed to be made between two parties, who according to the text of Littleton, s. 168 , being in law but one person, are on that account unable to contract with each other; and if the

\footnotetext{
${ }^{39} 2$ Esp 554. Likewise in Franks v. Duchess of Pienne, Lord Kenyon reportedly said that the Duchess 'must either have credit, or be starved'. The Times, 17 November 1797, 3.

${ }^{40}$ The Times, 5 August 1797, 4; 2 Esp 554.

${ }^{41} 2$ Esp 555.

${ }^{42} 8$ TR at 546.
} 
foundation fail, the consequence is, that the whole superstructure must also fail' ${ }^{43}$ He said this would introduce 'all the confusion and inconvenience which must necessarily result from so anomalous and mixed a character', and he listed a series of questions that would naturally follow if the plaintiff's argument were to succeed. He claimed that the plaintiff's argument rested only on the simple proposition 'that where the husband ceases to be the protector of his wife, and is not liable to have any claim made on him for her support and maintenance, it necessarily follows that she herself must be her own protectress, make contracts for herself, and be responsible for them'. ${ }^{44}$

Kenyon, having served as Master of the Rolls in Chancery before becoming Chief Justice of King's Bench, acknowledged that a feme covert could protect property to her separate use with a trust, and that courts of equity took notice of such trusts. Trusts, however, were not the province of courts of law. In the law courts, the 'unity of the persons' theory remained the rule, though a limited number of exceptions had crept in. Kenyon mentioned, for example, the situation 'of the husband being considered as dead, and the woman as being in a state of widowhood, or as divorced a vinculo matrimonii'. But Kenyon also referred to 'the cases of Ringsted v. Lady Lanesborough, Barwell v. Brooks, and some subsequent cases, which we wished to have reconsidered' ${ }^{45}$

Lawrence J's Paper Book for Marshall v. Rutton survives in Lincoln's Inn Library, and it contains extensive notes of the two arguments before all the judges. ${ }^{46}$ The notes allow us to see something of a sea change in judicial attitudes. Certainly the driving force behind the ultimate outcome in Marshall v. Rutton was Lord Kenyon, but he was aided by fortuitous alterations in the composition of the courts. When the case was first argued in May 1798, two of the justices who had voted with Lord Mansfield in the Ringsted, Corbett, and Barwell cases were still serving - Ashhurst J in King's Bench and Buller J, formerly in King's Bench but who in 1794 had transferred to the Court

\footnotetext{
${ }^{43}$ Ibid.

${ }^{44} \mathrm{lbid}$. at 547.

${ }^{45}$ Ibid. at 548 .

${ }^{46}$ Dampier MSS, LPB 329, Lincoln's Inn Library, London. Unless otherwise indicated, all quotations from the arguments of counsel and comments or speeches by the judges during the two arguments in the Marshall case are taken from Lawrence J's handwritten notes in the margins and on the reverse sides of the pages of his copy of the Paper Book. The full text of LPB 329 is available at J. Oldham (ed.), Case-Notes of Sir Soulden Lawrence 1787-1800 (Selden Society, forthcoming 2013), Part III.
} 
of Common Pleas. By the time the second argument was held two years later, Ashhurst J had resigned and Buller $\mathrm{J}$ was in failing health (he died a month after the second argument, which he did not attend). Also, Eyre CJ of the Court of Common Pleas, who attended the first argument, died in July 1799 and was replaced by the former Attorney General, Sir John Scott, newly created Lord Eldon.

At the first argument, the plaintiff was represented by Josiah-Iles Wathen; the defendant by Stephen Gaselee. Wathen cited most of the cases that have been discussed, relying especially on Barwell and Corbett. Gaselee, in response, questioned whether the facts of Marshall fell within the authority of the cases that were cited, pointing out that it was not within a married woman's power by her own acts to dissolve the civil contract of marriage, and that she could not bring suit by herself. Buller J at this point interjected: 'That depends on the custom of London not extending to the courts of Westminster.'

Lord Kenyon then distinguished the various authorities. He said that in the Duchess of Mazarine Case, 'the party was not in the country and was an alien [enemy] and therefore the law could take no notice of him'. As to his own decision in Franks v. Duchess of Pienne, 'There it was impossible to sue the husband and the purposes of justice required that there should be somebody sued'. Kenyon pointed out that in Ringsted, Lord Lanesborough was not in England, and Barwell v. Brooks involved 'nothing like a permanent fund'. Further, Kenyon claimed that Barwell had been 'overruled by Ellah v. Leah and Clayton v. Adams'. With regard to Corbett v. Poelnitz, Kenyon said that the first principle (that since the husband was not liable, the wife must be) would not hold, and the other principle that referred to the case of Govier v. Hancock ${ }^{47}$ was 'not decent for me to discuss' (it dealt with adultery). ${ }^{48}$ Kenyon remarked that some of the old law was 'very immoral'-it 'prevents the breach between husband and wife being healed'. The last observations from the bench recorded by Lawrence J for the May 1798 argument were the following weary remarks by Eyre CJ: 'I feel more difficulty from the authorities than from the principles. They [the principles] are with Lord Kenyon. I

\footnotetext{
${ }^{47}$ (1796) 6 TR 603.

${ }^{48}$ On the Govier case, see text accompanying nn. 103-6, below.
} 
do not know what to do with the authorities'. ${ }^{49}$

While the Marshall case was pending, at least four new cases dealing with creditors seeking to recover debts incurred by married women came before the common law courts. Two of the actions, one in the King's Bench and the other in the Common Pleas, were against the same defendant, Sophia Harris, who went by the name of Mrs Kitchen. Years earlier she had married John Wells, but for the past four or five years, she had been living with Mr Kitchen as his mistress, though passing as his wife. In the first of the two cases, Cox v. Kitchen, ${ }^{50}$ the jury verdict in the Common Pleas was for the plaintiff, conforming to the instructions of the trial judge, Rooke $J$, who told the jury that because the defendant's husband could not be liable (since his wife was living in a state of open adultery ${ }^{51}$ ), the wife must be liable herself. Relying on the Gilchrist case, ${ }^{52}$ Serjeant Williams filed a motion to set aside the verdict, but the full Court of Common Pleas upheld the jury verdict. ${ }^{53}$ Buller J (a Common Pleas justice since 1794) said that motions for new trials were governed by the court's discretion to do justice without any necessity to 'nicely examine whether the defendant be strictly liable in point of law' ${ }^{54}$ And since the husband was not liable, the wife must be, else 'she stands in a most miserable condition' - 'she can obtain no credit unless she be liable for her debt'. Heath and Rooke JJ concurred.

Three months later the case of Ciron v. Kitchen came before the Court of King's Bench on

\footnotetext{
${ }^{49}$ Eyre CJ's discomfort with the principles had, in fact, been clearly revealed to the practising bar in the summer of 1788 in an unreported case heard at the Devon assizes. In Harris v. Pyne, the issue was, 'whether a feme covert separated from her husband can maintain trover against a carrier for goods by him delivered to the husband'. Dampier Manuscripts, Dampier Briefs, brief no. VIII, Lincoln's Inn Library, London. See the Appendix for the facts of the case and for Eyre CJ's opinion. As is there shown, Eyre, even by 1788, thought that the cases might have gone too far, and he worried that he could not see a sensible stopping place. He said that he would be sorry to lay down a rule that would facilitate married women living separately. He acknowledged also that he did not think that, without trustees, an agreement before marriage could enable a woman to hold her property separately.

${ }^{50}$ (1798) 1 B \& 338.

${ }^{51}$ See below, text at nn. 102-9.

${ }^{52}$ Text following n. 102, below.

${ }^{53} 1$ B. \& P at 339-40.

${ }^{54}$ Ibid. at 339.
} 
the same facts except for the identity of the creditor-plaintiff and the amount of the debt. ${ }^{55}$ Garrow, counsel for the plaintiff, immediately relied on the Cox decision that had issued from Common Pleas. Erskine, counsel for the defendant, argued that merely because the husband was not liable, it did not follow that the wife must be. He claimed that the Cox decision was 'contrary to law'. Lord Kenyon said that he "certainly was fettered in such a way, that he could not possibly accede to the opinion given in the Court of Common Pleas'. He agreed with Erskine that the Cox case was 'contrary to law', and he 'rested on the case which was to be decided in the Exchequer Chamber [Marshall v. Rutton]'. He 'was confident that no new fashion of the times could alter the law of the land'. A jury verdict for $£ 16.16$ s. was taken, subject to the anticipated opinion in Marshall.

Another case that came before the Court of Common Pleas while Marshall v. Rutton was pending was De Gaillon v. L'Aigle. ${ }^{56}$ The defendant pleaded coverture to the plaintiff's suit in assumpsit on the common money counts. The defendant's husband was shown to be a resident of Hamburg, and the plaintiff claimed to have dealt with the defendant as a feme sole. Serjeant Runnington in argument for the plaintiff distinguished the case from Ringsted and Barwell on the basis that the defendant's separation from her husband was only temporary. Runnington argued that otherwise, if the court were 'to determine that the mere circumstance of the husband being out of the kingdom makes the wife liable, a feme covert may be subjected to an execution by her husband quitting the kingdom at a moment's warning ${ }^{57}$ Without allowing Serjeant Marshall to respond for the defendant, Buller J invoked 'another set of cases of a very different nature', namely, those in which the husband had been banished from England (Lady Belknap's Case ${ }^{58}$ ) or had been transported (Carruthers), so that the disability of the wife was suspended. Buller concluded that in the case before the court, the husband had voluntarily abandoned his wife, never was in England, and perhaps might never come there. He therefore ruled that, 'the wife has traded as a feme sole, has obtained credit as such, and ought to be liable for her debts'.

\footnotetext{
${ }^{55}$ See The Times, 16 February 1799.

${ }^{56}$ (1798) 1 B \& P 357.

${ }^{57}$ lbid. at 358.

${ }^{58}$ Coke on Littleton, $132 \mathrm{~b}$.
} 
The remaining case to come before the common law courts while Marshall v. Rutton was being decided was Marsh v. Hutchinson, ${ }^{59}$ arising in the Court of Common Pleas after Lord Eldon had become Chief Justice. The plaintiffs sued the defendant for the price of coals supplied during the previous three or four years, and the defendant pleaded coverture. Her husband had been in the British diplomatic service, and after that employment ceased, he settled in Holland. The case was suspended until Marshall v. Rutton was finally decided, ${ }^{60}$

Thus by the time the second argument before all the judges in Marshall took place on 10 May 1800, the plaintiff's position had grown precarious. Ashhurst JKB had resigned, Eyre CJCP had died and been replaced by Lord Eldon, and Buller JCP was too ill to participate. Morever the plaintiff's new counsel, Edward Law, was an unfortunate choice. Law later (in 1802) became Lord Ellenborough and succeeded Kenyon as Chief Justice of the Court of King's Bench. According to Sir William Holdsworth, Ellenborough's fundamental belief was 'that in a changing age it was possible to stand obstinately on the ancient ways' and to stand in 'opposition to all the changes in the law which new ideas and new conditions were making necessary'. ${ }^{61}$ It is clear from the colloquies between Law and the judges that Law did not have his heart in the case.

Law began with the basic argument that, 'if a woman [is] living separate from her husband having a competent maintenance for life defeasible by no act of the husband, and not defeated by any act of her own, [she] is capable of being sued as a feme sole'. Lord Eldon asked, 'But how is the deed valid that puts her in that state of separation'? Law responded: 'I can't find anything in the books as to that last point, but I find from the authority of the books that this separation is taken notice of in our courts and in the Court of Chancery'.

\footnotetext{
${ }^{59}(1800) 2$ B \& P 226.

${ }^{60}$ The report of the case by Bosanquet and Puller is dated 21 June 1800, but the case was heard before the second argument in Marshall v. Rutton on 10 May 1800. Near the end of the printed report (at 233), Bosanquet and Puller state: 'As the case of Marshall v. Mary Rutton, 8 TR 545, in which it was expected that the whole doctrine respecting the liability of a feme covert to be sued would be fully discussed, was then pending before the twelve judges, the Court desired that this case might stand over until that had been determined'. Lord Eldon had become Chief Justice of Common Pleas in July 1799, and after the Marshall decision issued, the court in the Marsh case affirmed the trial judge's conclusion that the defendant's claim of coverture was valid.
}

${ }^{61}$ W. S. Holdsworth, History of English Law (London: Methuen, 1952), vol. 13, 503. 
After further questioning by both Lord Eldon and Lord Kenyon, Law began to retreat. He stated: 'I consider Ringsted v. Lady Lanesborough, \&c. as modern revision and therefore do not press them. ... And if I can't contend that when the husband is not liable the wife is, I can't succeed'. Later, citing both Lord Coke and the Carruthers case $^{62}$, Law declared:

The effect I contend for at law is that which the courts have given in the cases alluded to and what the courts of equity have given.... Coke [on] Littleton 668 shows that the wife may come in if the husband does not protect her rights. I stand here for a principle. I admit this is not within the cases. If the principle that the husband not being liable is not a ground to charge the wife, I have no pretension to trouble the Court.

After the arguments were concluded by Law for the plaintiff and Serjeant Bayley for the defendant, Lord Kenyon reviewed the authorities once more, and gave the following unsurprising summary appraisal: 'I was never satisfied and therefore I wish[ed] this case should come to take away all difficulties. I have never had but one opinion about it'.

It was unclear, nevertheless, whether in Marshall the Court of King's Bench had overruled not only those cases where the husband and wife lived separately in England (Barwell, Corbett) but also those where the husband was out of the country (Ringsted, and the cases against the Duchess of Pienne) ${ }^{63}$ Arguably the principle of Ringsted survived whenever the husband was out of the country in circumstances that could be said to approximate 'civil death' - exile, abjuration, transportation for life; even, perhaps, transportation for a term of years. ${ }^{64}$ But the husband's residency abroad, without

\footnotetext{
${ }^{62}$ In response to Law's citation of Carruthers, Lord Kenyon interjected: 'That was but a nisi prius case and then the party could not come back during the seven years'. Kenyon failed to mention that Yates had taken the opinion of all of the judges in the Carruthers case.

${ }^{63}$ Henry Roscoe, in his editorial commentary in 1831 on the Ringsted case in volume three of Douglas' Reports, opened his comments with the following: 'Although this case came under the consideration of the Court of King's Bench, in Marshall v. Rutton, 8 T.R. 554, by which it is generally supposed to have been overruled, yet that consequence does not appear necessarily to follow; for in Marshall v. Rutton there was no averment that the husband resided out of the jurisdiction of the English courts, as in the principal case': 3 Doug 204.

${ }^{64}$ In Carrol v. Blencow (1801) 4 Esp 27, an action in assumpsit was brought in the Court of Common Pleas for goods sold and delivered. The defendant's husband had been transported for seven years, but the seven years had expired, and the plaintiff's counsel therefore argued that the defendant's claim of coverture should not succeed. Richard Pepper Arden, created Lord Alvanley, had succeeded Lord Eldon as Chief Justice of the Court of Common Pleas on 22 May 1801. He rejected the plaintiff's argument, holding that the defendant's husband
} 
more, would not do, as had been demonstrated by the outcome (though without a final opinion) in Marsh v. Hutchinsin when Lord Eldon was Chief Justice of the Common Pleas. Several years later the case of Farrer v. Granard ${ }^{65}$ came before the Common Pleas, in which the defendant pleaded coverture. The plaintiff replied that defendant's husband lived in Ireland, and the defendant lived in England as a single woman, in which capacity she had promised to pay. Sir James Mansfield, who had been appointed Chief Justice of the Common Pleas less than two months before the case was argued ${ }^{66}$ rejected the plaintiff's claim, stating: 'The terms of the replication are perfectly consistent with a mere temporary absence. They might be applied to the case of every man who goes for a short time to live in Ireland or Scotland, and whose wife in the meantime contracts debts here' ${ }^{67}$

Similarly, in Boggett v. Frier, ${ }^{68}$ the Court of King's Bench upheld the defence of coverture even though the defendant's husband 'had four years before deserted her and gone beyond seas without leaving her any means of support, and ... had not since been heard of by her'. The court under Ellenborough CJ said that the cases cited by the plaintiff 'were antecedent to that of Marshall v. Rutton; and, so far as they were opposed to [it], were overruled by that decision, which restored what was the old established rule of law, founded generally upon the relation of husband and wife, by which, with certain known specific exceptions, no married woman was capable of contracting or acting as a feme sole, or of suing or being sued as such'. ${ }^{69}$

Finally, before turning to the question of 'necessaries', it is worth noting that the Court of King's Bench faced once more the Duchess of Pienne, who had ducked for cover yet again behind her

had effectively abjured the realm after his term of transportation had ended. No reference appears in Espinasse's report of the case to either Marshall v. Rutton or Marsh v. Hutchinson.

${ }^{65}$ (1804) 1 B \& P NR 80.

${ }^{66}$ Sir James Mansfield took office as Chief Justice on 24 April 1804 after Chief Justice Alvanley had died on 19 March.

${ }^{67}$ Ibid. at 81 . Serjeant Best had cited the case of De Gaillon v. L'Aigle on the plaintiff's behalf, but Heath J said that the De Gaillon case 'proceeded much upon the ground of the Defendant's husband being a foreigner'. See text at nn. 56-8, above.

${ }^{68}$ (1809) 11 East 301.

${ }^{69}$ Ibid. at 303. 
absent husband. In Kay v. de Pienne ${ }^{70}$ the Duchess was sued on a promissory note. Her husband had returned to England from France sometime after the first round of litigation in $1797 .^{71}$ The Duke, however, had decamped again, this time in 1803 'to enter into the service of Sweden' ${ }^{72}$ Garrow, for the plaintiff, relied on Lord Kenyon's earlier decisions upholding jury verdicts against the Duchess, as if a feme sole. Ellenborough CJ was unreceptive. He said he did not know whether Lord Kenyon had realised that the Duke had been living with his wife in England before returning to France. If so, said Ellenborough, 'I cannot subscribe to his opinion', and in any case, the Ringsted and Corbett decisions had not then been judicially overturned. Ellenborough said that, 'Since the case of Marshall v. Rutton ... which restored the old common law upon this subject, I consider it quite clear that a married woman, under the circumstances of the present defendant, is not liable to be sued as a feme sole ${ }^{73}$ According to The Times, a nonsuit was entered at Garrow's request. ${ }^{74}$ Subsequently, on 25January, 1812 Abbott moved for a new trial on the Duchess's behalf but was rebuffed. Lord Ellenborough reiterated that Lord Mansfield's doctrine in Corbett v. Poelnitz 'had been since overset'. Also, 'it appeared that Lord Kenyon was wrong in his prophecy' that the Duke had deserted the kingdom, and if the plaintiff were permitted to prevail, 'it would sanction the arrest of every married woman whose husband should go abroad upon the service of his country'.

\section{Necessaries and the Tradesmen's Dilemma}

As has by now become obvious, the position of the tradesmen and merchants who dealt with women customers was delicate. Outside the confines of the City of London, extending credit to women who presented themselves as femes sole was risky business. After Marshall v. Rutton, there

\footnotetext{
${ }^{70}$ (1811) 3 Camp 123.

${ }^{71}$ See the discussion of Walford v. de Pienne and Franks v. De Pienne, text at nn. 38-9, above.

72 Camp 123.

${ }^{73}$ Ibid. at 124-5. According to The Times, 6 December 1811, 3, Lord Ellenborough said that Lord Mansfield's Corbett doctrine 'had been completely exploded'.

${ }^{74}$ Ibid.
} 
were very few situations that would permit the merchants to recover judgments against married women, even when the husbands were beyond reach or could not be held liable. One semi-safe harbour, however, was when the goods sold or services rendered appeared to be 'necessaries', for which husbands would ordinarily be responsible. Yet even these situations were uncertain. Did the customer live with her husband in marital contentment, such that all transactions would be the husband's responsibility? Or would her husband's implied consent extend only to 'necessaries', and if so, what goods and services did the wife's 'station in life' encompass as 'necessaries'? How was the appropriate 'station in life' to be determined? Did the financial condition of the husband matter? If the husband and wife lived separately, did the wife have a separate allowance? If so, was her allowance adequate to support the station in life to which she was entitled? These and other such questions bombarded the judges.

In an unreported 1787 nisi prius case tried by Buller JKB, Shepherd v. Smith, ${ }^{75}$ a creditor sued for payment for necessaries provided to the defendant's wife. The defence was that the wife had left of her own accord and had behaved very improperly ('she had sometimes been in liquor and raised broils in the street'). The plaintiff replied that prior to the wife's leaving, the defendant had behaved badly toward her, for example by keeping his mistress in the house. Buller $\mathrm{J}$ instructed the jury as follows:

The law is thus. If a woman wilfully and without any reasonable cause leaves her husband's house and lives elsewhere without his consent, there he is not liable for any debts which she may contract. But if he thrusts her out of doors, or acts in such a manner as renders it impossible for her to continue under the same roof, as by keeping a mistress under her nose, there he sends her out with a credit upon all the world, for such things as are necessary for a person in a situation of life which he himself holds and he is liable for so much. ${ }^{76}$

Accordingly, the jury found for the plaintiff.

As Buller J stated, the level of support to which the wife was entitled was to be measured by

\footnotetext{
${ }^{75}$ Buller and East, Misc. MS 97, 132v, sittings after Easter Term, 1787, Westminster Hall.

${ }^{76} \mathrm{Ibid}$. at $132 \mathrm{v}-133$. Buller 'also added that in the latter case, if he wishes to put an end to her credit, he must apply to her to come back and live with him'.
} 
the husband's 'situation in life'. Put another way, there was a clear recognition by the judges that husbands were to be protected against spendthrift wives, provided that husbands did their best to keep their wives under control. The report in The Times of the 1793 case of Dyde v. Bewicke began as follows: 'This is an action of the greatest importance to every husband in the kingdom, who has the misfortune to have an extravagant wife, to all haberdashers, milleners, and to tradesmen in general' ${ }^{77}$ The defendant was a clergyman. Erskine, in the clergyman's defence, said that it seemed to be presumed by the plaintiffs that a husband was responsible for whatever his wife might chuse to purchase', but 'could this authority possibly cover two cloaks (accounting for more than half of the plaintiffs' bill) that could not without disgrace be worn by the wife of a person of a degree no higher than this clergyman'? Lord Kenyon understood the point. He said that 'if this Bill was to be supported up to its full extent, there was no person in the kingdom almost, however low his degree in life might be, who might not, in a few months, be called upon to answer for contracts made by his wife up to an extent that might ruin him'. Kenyon admitted that, 'One was sorry that tradesmen of reputation should be losers, but when they carried their goods to market, they ought to carry common-sense and common prudence along with them and ought to have made enquiry who this woman was' ${ }^{78}$ The jury 'immediately found a verdict for the defendant'.

Likewise in Dawson v. Gildert, a clergyman defendant was held not responsible for his wife's purchase of millenary articles. Erskine, for the defendant, described the wife as 'in the wane of beauty' but 'still retaining the most passionate fondness for splendor of dress'. After paying one bill to the plaintiff, the defendant had 'strictly enjoined her [the plaintiff] not to give his wife any further credit'. Lord Kenyon said that if the plaintiff were to recover her demand 'after she had received the notice not to trust the Lady, there could be no domestic security' - the clergyman was only 'bound to

\footnotetext{
${ }^{77}$ The Times, 2 July 1793, 3.

${ }^{78}$ The action was brought to recover on a bill for $£ 92.15 \mathrm{~s} .9 \mathrm{~d}$. The clergyman's annual income was $f 230$ to f250. A witness for the defendant, Miss Foster, was in the shop when the defendant's wife made her purchases. Miss Foster said that the wife 'appeared to be a lady of fashion, and spoke to Lady Hawke, Lady Turner, Lady Say and Sele, and to other ladies of fashion, as if she had been acquainted with them'. Miss Foster 'thought it would have been rude and impertinent to have asked the defendant's lady who she was'. This testimony provoked sarcastic commentary by Erskine: 'When a woman was taken to be a woman of fashion after she had been rigged out in one shop, she might go in full sail into another; and if she spoke to Lady Hawke, Lady Say and Sele, or any other Lady of Fashion about gauze, ribbons, pads, or any other fashionable commodity, she herself forsooth was to be taken to be a woman of fashion also': Ibid.
} 
pay the debts of his wife which were contracted for articles consonant with his rank in life' ${ }^{79}$

On occasion, a wife would resort to stealth and deception. In Bentley v. Griffin ${ }^{80}$ the plaintiffs, dressmakers, sought payment for fashionable dresses furnished to the defendant's wife. The defendant and his wife lived together; he was an attorney who depended on his modest practice for income. His wife borrowed a friend's curricle to convey her in style to the plaintiff's shop and later instructed the servants to put the dresses away so that her husband might not see them. Against the instructions of the trial judge (Heath J), the jury awarded the plaintiff the full $£ 183$ demanded, prompting a subsequent motion by Serjeant Best to set aside the verdict. In opposition, Serjeant Vaughan cited 'the doctrine of Ellenborough C.J. in the case of Waithman v. Wakefield, 1 Campb. 120, that however low a man's circumstances may be, if he allows his wife to assume an appearance which he is unable to support, he is answerable for the consequences' ${ }^{81}$ Heath, Chambré, and Dallas JJ, however, thought the verdict wrong ('grossly wrong', according to Chambré) and ordered a new trial. ${ }^{82}$ The second jury returned a verdict of only $£ 15.15 \mathrm{~s}$., 'the price of a black dress, which it appeared the husband had seen her try on'. 83

\footnotetext{
${ }^{79}$ The Times, 1 December 1801, 3.

${ }^{80}$ (1814) 5 Taunt 356.

${ }^{81}$ Ibid. at 537.

825 Taunt 358; see also The Times, 12 February 1814, 2.
}

${ }^{83}$ The Times, 30 May 1814, 2. This outcome corresponded to views not only of the Common Pleas judges but also to predecessor judges on the courts of Exchequer and King's Bench. A notebook originally belonging to Edward Clive (JCP 1753-70), passed on to Buller J, then given by Buller shortly before his death to Soulden Lawrence (JCP 1794, 1808-12; JKB 1794-1808) contains the following case note:

Baker v. Baker at the sittings at Guildhall 11 Feb 1726 Coram Pengally Ch[ief] Baron--he cited the Case of Keniston v. Beau Goodall of Grays Inn, which was tryed before Holt Ch[ief] J[usti]ce. The case was Michaelmas 1705. A Tradesman brought an action against the husband for money due to him for the price of some fine cloaths, which the wife had bought of the plaintiff, unknown to the husband. It appeared upon evidence that during the time of a constant cohabitation, the wife, without the privity of the defendant her husband had bought a rich suit of apparel \& carryed them to a friend's house, where she dressed, went to plays, operas, \& other places of publick resort, and when these amusements were finished, she undressed at her friend's house \& returned to her husband in her usual dress. And the question was how far the husband was chargeable to pay the plaintiff for these cloaths. Lord Chief Justice Holt held he was not chargeable at all because they never came to his eye, because the secret manner in which she dressed \& used the cloaths entirely disengag' $d$ the husband from any presumption that he consented to the buying of them; neither could they be reasonably comprised under the notion of such necessary cloathing every husband is obliged to afford his wife, and therefore he ought not to pay for them. But held it would have altered the case greatly if it had appear'd she had ever worn the cloaths in her husband's company. 
Lord Ellenborough in Waithman v. Wakefield did indeed say that a husband was answerable for improvident purchases by his wife if the husband adopts her actions by failing to control her, even if the wife is 'unmanageable and disobedient' ${ }^{84}$ But he also said that 'it is the duty of tradesmen to make enquiries before trusting a married woman who is a stranger to them, ${ }^{85}$ The defendant in Waithman was a young attorney, recently called to the bar, who had married while a law student. His wife turned out to have a violent temper, reducing her husband to a state of misery. According to a newspaper report of the case, the defendant's counsel, Attorney General Vicary Gibbs, called the wife one of the most notorious swindlers that ever infested this city - 'Nothing could exceed the art which the family of Mrs. Wakefield exhibited in carrying on their nefarious practices' ${ }^{86}$ Ellenborough told the jury that since the plaintiffs trusted the defendant's wife without making any inquiry about her, 'if they receive a verdict at all, their demand should be reduced to the charge for necessaries suitable to the circumstances of the defendant' ${ }^{87}$ But the jury, 'notwithstanding gave the plaintiffs a verdict for the full sum of $£ 34.13 s,{ }^{88}$

The 'necessaries' cases reflect the marital mores of the time that called for wives to be subservient and financially prudent. Wives who misbehaved could not expect much sympathy from the courts, though this depended in some measure on the nature of the misbehaviour. Wives on shopping sprees seem trivial compared to another situation that generated claims against husbands to cover necessaries supplied to wives, namely, when the wife fled the marital home. Here, the reason for the wife's departure was important. Buller J in Shepherd v. Smith said that a wife would retain her right to necessaries if she left home because her husband had made her continuation under the same

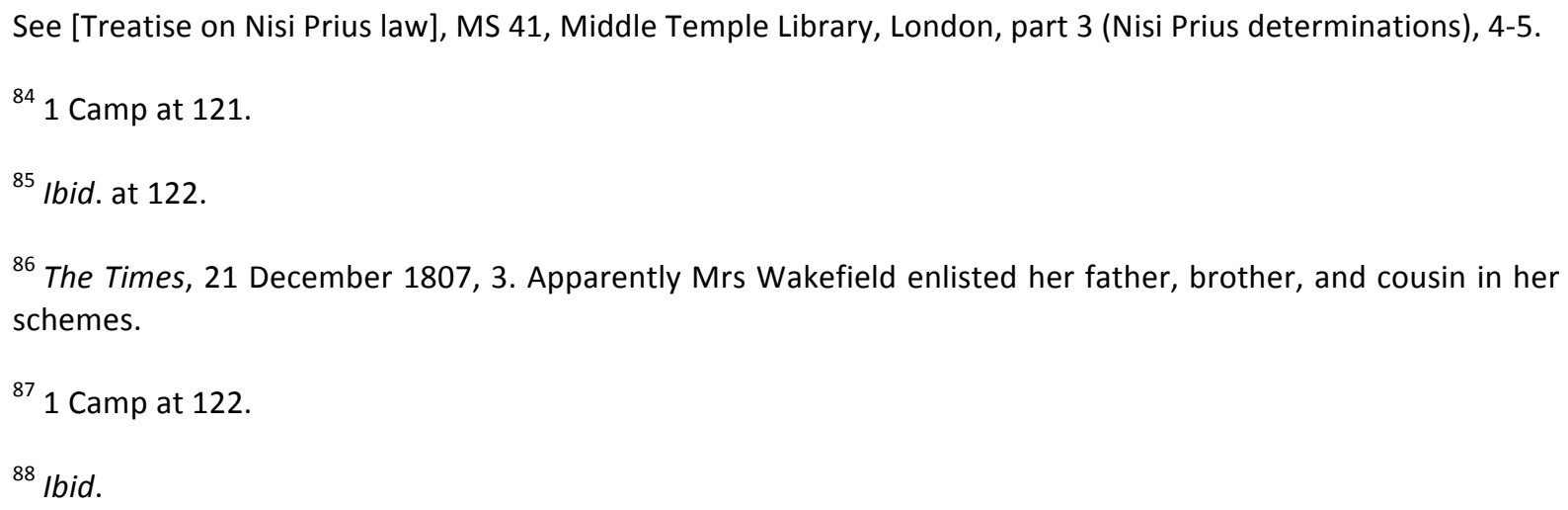


roof intolerable, as by keeping a mistress under her nose. ${ }^{89}$ A decade later, Lord Kenyon CJ in Hodges v. Hodges ${ }^{90}$ reframed the critical inquiry. The defendant's wife, after being beaten repeatedly by him, took the young children and went to live with her adult son, the plaintiff, who provided board and lodging and funds for education expenses. ${ }^{91}$ The plaintiff sued the husband in assumpsit for recompense. Lord Kenyon could not get the parties to agree to arbitration, but he finally coaxed them to settle. According to Peake's report, Kenyon said that 'the case itself would be attended with difficulty in point of law, and complete justice could not be done'. He gave the following explanation: If a husband turned his wife out of doors he sent a credit with her; and . . . he [Lord Kenyon] was inclined to ... say, that if he [the husband] behaved in such a way as to render it unsafe and dangerous for her to reside with him, that in that case the plaintiff would be entitled to recover [from the husband] for the board of the wife; further he could not go, for the wife might apply to the Spiritual Court for a divorce' ${ }^{92}$

There was a sharp difference between the formulation of the basic rule by Buller $\mathrm{J}$ in Shepherd and that by Lord Kenyon in Hodges. It was one thing for the wife to be unable to continue under the same roof because of her husband's beastly behaviour, but quite another to require that it be 'unsafe and dangerous' for the wife to remain.

Kenyon's successor, Lord Ellenborough, appears to have been more in line with Buller than with Kenyon. In Brannan v. Dodds, ${ }^{93}$ the plaintiff had supplied board and lodging to the defendant's wife, and the plaintiff's counsel argued that the defendant was responsible for his wife's expenses whenever the husband's maltreatment rendered 'her stay in his family dangerous to life or limb, or destructive of her peace', causing the wife to take refuge elsewhere. Agreeing, Lord Ellenborough

\footnotetext{
${ }^{89}$ Quoted above, text at n. 76.

90 (1796) Peake Add Cas 79, also reported at 1 Esp 441.

${ }^{91}$ The defendant was apparently the plaintiff's father, based on Lord Kenyon's reference to 'the near degree of relationship' between the parties.

92 Peake Add. Cas. 79. Kenyon also said that there was nothing he could do for the children-that the law obliged the defendant 'to nothing but nurture, which duty expired when the child reached the age of seven', Ibid. at 80.

93 The Times, 29 February 1804, 3.
} 
instructed the jury that if the wife 'experienced such brutal treatment as to render it impossible for her to live with her husband, then she had a right to get credit upon his account for the necessaries of life'. The jury verdict was for the plaintiff for $£ 15.13 \mathrm{~s} .1 \mathrm{~d}$.

Yet Lord Kenyon's harsher version of the basic rule prevailed for many years in the Court of Common Pleas. In Horwood v. Heffer, ${ }^{94}$ the husband (the defendant) was held not to be liable for necessaries supplied to his wife despite his despicable behaviour toward her. He had 'taken another woman into the house, with whom he cohabited', and 'had confined his wife in her chamber under a pretence of insanity'. The wife escaped, and the suit was for necessaries furnished to her afterwards. At trial, Lawrence J nonsuited the plaintiff because there was no proof of the wife's 'apprehension of her personal safety', and 'however abhorrent from the feelings of a delicate woman, she might nevertheless have had necessaries, if she had staid there. She might, if she had thought fit, have sued for alimony, and a divorce $a$ mensâ et thoro ${ }^{95}$ The nonsuit was upheld by the Court of Common Pleas. Preserving jurisdictional boundaries, Sir James Mansfield CJ declared: ‘If this suit were maintainable, it would be necessary that the jury should, in the first place, determine whether the wife lawfully left her home or not; this would wholly supersede the necessity of a suit for alimony, or a divorce $a$ mensâ et thoro. I think nothing short of actual terror and violence will support this action'. ${ }^{96}$

Counsel for the plaintiff in Horwood was William Best. In 1818, Best became a King's Bench judge, and in 1824 he was appointed Chief Justice of the Court of Common Pleas. The following year the case of Houliston v. Smyth ${ }^{97}$ came before the Common Pleas with facts quite similar to those in Horwood. The plaintiff in Houliston sued for the use and occupation of rooms and for necessaries furnished to the defendant's wife. The defendant had abused his wife, even for a time confining her to a private madhouse. The wife eventually could take no more and left. At trial, Best CJ said that, 'A man in the plaintiff's situation cannot recover, unless the wife be at his house with the assent of the husband, or unless the husband drives her from her home by cruelty, personal violence, or that which

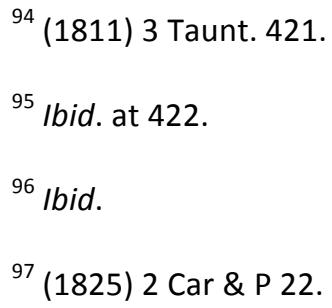


shall excite reasonable fear of personal violence, for in such case he sends her out with a general credit'. ${ }^{98}$ As to Horwood v. Heffer, Best declared, 'I was dissatisfied with the decision at the time, and have continued so ever since; and if this case had come to that point, I had determined to have it reconsidered, ${ }^{99}$

Serjeant Vaughan then took the case before the full Court of Common Pleas on a motion for new trial, and notwithstanding Best CJ's comments at trial, cited Horwood v. Heffer on the defendant's behalf. Best interrupted Vaughan to ask whether he was aware 'of a late case [Aldis v. Chapman] in which Lord Ellenborough at N.P. [nisi prius] expressly overruled Horwood v. Heffer? ${ }^{100}$ Best said that if he had known about the Aldis case at trial, he 'would have ruled that Horwood v. Heffer was not law, it being against the first principles of morality'. Park J emphatically agreed, asking, 'Is the mistress of a family to give way to a common prostitute?' Park expressed surprise at the language of Horwood, declaring: 'Taken to its full extent, it is abhorrent to every feeling of a man, and every duty of a moralist and a Christian; for it is said, that although a husband places a profligate woman at the head of his table, and tells his wife that she may dine in her own room, yet she is not justified in quitting his house, but should sue for alimony or a divorce a mensâ et thoro'. ${ }^{101}$

In cases where the wife was shown to have eloped with a lover or to be living separately in adultery, the husband's responsibility for his wife customarily ended. Unsurprisingly, Lord Kenyon hated to dirty his hands with these cases. In Gilchrist v. Brown, the defendant, on being sued as a feme sole, pleaded coverture, to which the plaintiff replied that the defendant had left her husband and was

\footnotetext{
${ }^{98}$ Ibid. at 27. Best's statement of the basic rule closely resembles that of Buller J in Shepherd v. Smith, text at $\mathrm{n}$. 76, above.

99 Ibid. at 28.

$100 \mathrm{lbid}$. at 29. The Aldis case, decided at the Middlesex sittings after Trinity Term 1810, was apparently unreported except for a one-sentence description in Selwyn's Nisi Prius (W. Selwyn, The Law of Nisi Prius (London, 1823), vol. I, 207).

${ }^{101} \mathrm{Ibid}$. at 30-31. Burrough and Gazelee JJ concurred.
} 
living separately in adultery. ${ }^{102}$ The court asked counsel for the plaintiff whether there was any precedent to support her replication, and on being told that 'there was no case precisely similar', immediately ruled for the defendant, because there was no separate maintenance (as there had been, for example, in Corbett).

In Govier v. Hancock, ${ }^{103}$ the prevailing double standard for husbands and wives was exhibited with shocking clarity. There, the plaintiff sued for necessaries furnished to the defendant's wife. The defendant had previously 'treated his wife with great cruelty', having brought his mistress to live in the house and eventually turning his wife out of doors. ${ }^{104}$ Later, the wife committed adultery herself, living with another man for a time, but after he left her, she incurred the expenses for which the suit was brought. The court said that the governing principle was 'that the husband is not liable in cases where the wife goes away with an adulterer'. ${ }^{105}$ When counsel for the plaintiff pointed out that the expenses had been incurred when the wife was no longer living in adultery, Lord Kenyon was unimpressed. He said that in order to learn what the law was on whether a man was obliged to take back his wife after she had been living in adultery with another man, 'it was as clear as the sun' - 'it was only necessary to consult one's feelings' ${ }^{106}$ The plaintiff was nonsuited.

In the context of adulterous behavior, Lord Kenyon CJ and Buller J, yet again, showed

\footnotetext{
102 (1792) 4 TR 766. The defendant was said to be living 'in adultery' despite having apparently received a divorce a mensa et thoro.

103 (1796) 6 TR 603.

${ }^{104}$ Hancock reportedly brought into his house not only his mistress (a married woman) but also two children Hancock had by her: The Times, 15 April 1796, 3.

${ }^{105} 6$ TR at 604.

${ }^{106}$ The Times, 15 April 1796, 3. To add insult to injury, the court noted that, 'if the wife had instituted a suit in the Ecclesiastical Court against the husband for restitution of conjugal rights, they would not have assisted her': 6 TR at 604. The result reached in the case could place the wife in a position to be unable to receive any further credit, even for necessaries. Apparently Lord Kenyon was unconcerned about whether an adulteress might be starved, no matter how insufferable the husband's behaviour had been before he threw his wife out of the house. (Compare Kenyon's comments in the Duchess of Pienne cases, nn. 38-39, above, and accompanying text.) In the words of one author, these cases tested whether there were "moral, physical, and legal limits to what a wife should endure:" S. Lloyd, 'Amour in the Shrubbery: Reading the Detail of English Adultery Trial Publications of the 1780s', (2006) 39 Eighteenth-Century Studies 421, 426.
} 
sharply contrasting philosophies. In Norton v. Fazen,${ }^{107}$ the defendant was the cuckolded husband who left home after discovering his wife's adultery. The Court of Common Pleas held the defendant liable for necessaries supplied by the plaintiff to the defendant's wife and children because there was no proof that the wife's affair was known to the plaintiff or was so notorious that it should have been known. Buller J said that the case was anomalous; nevertheless:

The wife committed adultery for a considerable time while she was living with her husband; he voluntarily yielded his bed to the adulterer, and made no provision for her. Then what colour of defence is left? Knowing of her criminal conduct and having made no provision for her, he must maintain her as before. ${ }^{108}$

Other judges, like Buller J, were not fettered by the strict moral code that governed Lord Kenyon. In the Houliston case, Serjeant Vaughan, counsel for the defendant, offered to prove the wife's adultery. At nisi prius, Best CJ rejected the proof, stating: 'The receiving such evidence might give the husband, in some cases, the liberty to take advantage of his own profligacy, as he might have driven her to such behaviour by his bad conduct'. ${ }^{109}$

\section{Conclusion}

The Court of King's Bench in Marshall v. Rutton (1800), under Kenyon CJ, overruled earlier King's Bench decisions by Lord Mansfield that had allowed creditors to prevail in suits against married women in an expanding set of factual circumstances. As Kenyon confessed in Marshall, he had never been satisfied with the Mansfield decisions, and had wished that a case 'should come to take away all the difficulties'. The Marshall case fulfilled his wish. Kenyon, however, was not the powerful leader of King's Bench that Mansfield had been, and but for fortuities of judicial turnover, the turnabout in Marshall might not have happened.

107 (1798) 1 B \& P 226.

${ }^{108} 1 \mathrm{~B} \& \mathrm{P}$ at 227. Eyre CJ was sympathetic to the defendant, observing that if the defendant could 'bring it home to any other tradesman who shall be in the same situation as the present Plaintiff, that he did know or ought to have known the circumstances under which the wife was living, the Defendant may perhaps be able to prevent another verdict passing against him'.

${ }^{109} 2$ Car \& P at 23-24. 
The fact that newly appointed judges find ways to effect change while pretending to honor stare decisis is hardly surprising. It is nonetheless important where possible to make the historical record transparent. Lawrence J's manuscripts allow us to see behind the curtain in the influential case of Marshall v. Rutton.

The moral high ground occupied by Lord Kenyon on the subject of marriage was shared by other common law judges of the time, and the creditors who assumed or who were duped into thinking that they were dealing with femes sole were often left unrecompensed. After Marshall, this occurred whenever the wife was the defendant and she could prove her coverture, except in the rare cases when the husband was out of the country in circumstances that could be said to be equivalent to civil death. And even if the husband could be found in England and sued, he could not be held liable not even for necessaries - if the wife left the home 'willfully and without any reasonable cause, ${ }^{110}$ most commonly when she eloped in adultery with a lover.

${ }^{110}$ Buller J in Shepherd v. Smith, text at n. 76, above. 


\section{APPENDIX}

\section{Harris v. Pyne}

Information about this unreported case, tried at the Devon summer assizes in 1788, can be found in the brief sent to Serjeant Soulden Lawrence, now part of the Dampier Manuscripts in Lincoln's Inn Library, London. (See Edmund Heward, 'The Dampier Manuscripts at Lincoln's Inn' (1988) 9 Journal of Legal History 357.) The brief is no. VIII in a box misleadingly labeled 'Dampier Briefs'. Most of the briefs within were those of Serjeant Lawrence during his years of active practice before the Court of Common Pleas, 1787-94, after he was made Serjeant-at-Law in Hilary Term 1787. (His practice previously had been predominantly in the Court of King's Bench. He was made a junior Justice of Common Pleas on 8 March 1794.) The issue in Harris v. Pyne (quoted in n. 49, above) is in Lawrence's handwriting beside the caption on the folded brief that was sent to Lawrence for a fee of three guineas. On the reverse sides of the pages of the brief are Lawrence's notes of arguments of counsel and of the opinion by Eyre CJ.

According to the brief, the plaintiff, a widow, married Edward Harris in 1784 after a marriage settlement had been executed, dated 13 November 1784. Two years later, the marriage failed, and the plaintiff on 9 December 1786 moved out, commencing divorce proceedings on 26 January 1787 for cruelty. Mr Harris then preferred at the quarter sessions an indictment against his wife for assault, which was removed to the Court of King's Bench, coming on for trial at the Lent Assizes 1787. The dispute was referred to arbitration and an award was issued, ordering among other things that $\mathrm{Mr}$ and Mrs Harris were to live separate and apart from each other.

The plaintiff in her brief itemised the contents (clothing and household linens) packed in two boxes and two trunks that were by contract to be carried by the defendant from Topsham to Alphington, where the plaintiff had taken up residence. The plaintiff alleged that Pyne the carrier (the defendant), in collusion with Mr Harris, allowed the carriage to be stopped on the King's highway in Alphington, after which the boxes and trunks were removed and released to Mr Harris. The principal parts of Eyre CJ's opinion, as noted down by Serjeant Lawrence, were as follows: 
This is a new case. I should be sorry to lay down a rule to facilitate married women living separate. I doubt if Courts of Justice have not gone too far. The first case proceeded on an apparent necessity. ${ }^{111}$ I do not at all wonder that when the consequences of the first determinations were seen that it was found necessary to go further - and when she was held liable for necessaries, I see no good reason for stopping short of all contracts - and therefore I do not think the last case wrong if the first [was] right.

This [case] however is going one step further - this involves the question if the husband has divested himself of his rights in the wife's property. And if the husband has not divested himself, the delivery is good.

The situation of a feme sole liable to be sued must be presumed to arise out of the contract of separation; so [also] her power to contract - for if she separated voluntarily, she could not contract. Without trustees, I do not think an agreement before marriage could enable a woman to hold her property separately. [An] order of nisi prius ${ }^{112}$ may be as good a way to live separate - [it] may be as good a way as any - but no provision [is] there as to the property of the wife. All I presume the courts thought necessary to look to as to separate maintenance was to see that she had something to live on.

Here I shall incorporate the original settlement with the order of separation, just as if it was provided for in the Act of Separation. What are to be the consequences of the contract for a separate maintenance must be determined from the terms of the contract. It has been rightly asked, does it apply to after-acquired property? . . ${ }^{113}$

I choose to determine this on the general ground - that nothing should prevent a

\footnotetext{
${ }^{111}$ Undoubtedly Eyre was referring to Ringsted v. Lady Lanesborough, text at nn. 13-16, above.

112 Here Eyre $\mathrm{CJ}$ is referring to the fact that the arbitration award ordering $\mathrm{Mr}$ and Mrs Harris to live separately had been made a rule of court, i.e., an order by the trial court (an 'order of nisi prius').

${ }^{113}$ Gibbs here stated the case of Haslington v. Gill [3 Doug. 415 (1784)], in which the Court of King's Bench upheld a marriage settlement assigning to trustees a herd of cows for the wife's separate use, and the court allowed the profits and produce from the cows during the marriage to be included. Eyre CJ responded, 'I do not quarrel with that. It was a trading stock'. Gibbs then attempted an analogy - 'The wearing apparel must be the produce of the separate property' - but Eyre CJ then stated his resolution of the case.
} 
husband receiving from a carrier. Had this been the case of wearing apparel only, I might perhaps have been of opinion with the lady. My opinion is that two boxes, contents unknown, delivered to the carrier and afterwards to the husband is a good delivery.

Although the case was not one 'of wearing apparel only', the Declaration itemised the contents of the boxes and trunks, and in addition to household goods, wares, cloth, and linens, the following clothes were listed: ' 1 bombazine gown and petticoat, 1 black silk gown $\&$ petticoat, 1 black satin quilted petticoat, 2 black silk aprons, 2 black silk handkerchiefs, 3 black silk mode cloths, 3 chintz gowns, 1 striped Holland gown \& petticoat,'. These clothes, plus '100 yards of black lace, 100 yards of trimmings, 100 yards of bone lace', were characterised in the Declaration as 'necessary wearing apparel of Plaintiff's of large value, to wit of the value of $100 £$ '. 